\title{
A BRIEF DISCOURSE ABOUT THE NEED FOR CRIMINALIZATION OF ONLINE GROOMING IN BOSNIA AND HERZEGOVINA
}

\author{
Ena KAZIĆ-ÇAKAR \\ Assistant Professor, Faculty of Law, International University of Sarajevo \\ E-mail: ekazic@ius.edu.ba
}

\begin{abstract}
The imperative for "law to be stable but not to stand still", given by R. Pound can be easily understood in recent years within the theory and the practice of criminal law. Many new socially negative phenomena have emerged recently and spread rapidly, and they require the right reaction from states in order to criminalize them and ultimately to prevent them. Sexual offences confirmed the evolution of criminalization, but when one adds the internet and computer sphere to this already challenging group of criminal offences, it brings us to another dimension of legislation and space for achieving the above-mentioned legal imperative. Just as many international legal sources confirmed the necessity and obliged member states to criminalize online grooming, and just as many states from the comparative law successfully have approached this legislative matter, in this article we test the readiness of Bosnia and Herzegovina to undertake that criminalization. The aim of the paper is to provide arguments in favor of the criminalization of online grooming of children in the entire territory of Bosnia and Herzegovina, as it is being criminalized only partially, which opens the question of harmonization and non-discrimination of citizens of that state.
\end{abstract}

Keywords: Children, Sex Offence, Internet, Communication Technologies, Criminal Law of Bosnia and Herzegovina 


\section{Introduction}

Some decades ago, the internet was developed for military purposes. At the time of its emergence into the wider society, it was hard to believe that one day it would be easily accessible, that it would be part of our daily life, not only as an indispensable means of communication but also a means of work, education, culture. It became a very important part of our lives, regardless of age, gender or location of its user. That "appealing online space, that offers individuality, anonymity, self-promotion and role-playing according to wishes of users" (Broadband Commission, 2011, p.5), no matter how beneficial it is, when misused, it may create severe consequences which is a matter of concern in modern time. Interestingly, "until recently there has been little recognition of the danger that may also result with it" (Stanley, 2001, p. 1).

Children as a particular group of individuals, due to their incomplete psychological and physical development, often fail in differentiating good from bad and in identifying the danger, which makes them additionally vulnerable and endangered from the criminal offences perpetrated through the internet. For the purposes of this article, sex offences that may be perpetrated against children through the internet are objects of our interest. The reason for that is simple: the quantity of their perpetration has increased proportionally with the extent of use of internet. In 2010 Internet Watch Foundation "has identified and taken action against 16,700 instances of child abuse" (Broadband Commission, 2011, p. 2), while World Health Organization estimates there are "200 million children that are being sexually abused online" (Broadband Commission, 2019, 31). Many of the benefits of the use of the internet, when used for bad purposes, became important factors that may facilitate criminal conduct. It is easy for children to access this material. They become users in their young age. In many cases their parents cannot follow the use of their children or observe them accordingly. That is how the surveillance-free space is created, and is abused by perpetrators. Moreover, according to Klimek (2020, p.8), "many parents are of the opinion that children are safe in their own homes. There is no stranger at home and therefore there is no risk for children playing at home" and he correctly concludes that they "underestimate the negative power of internet".

This type of criminal offence has dual nature: the internet is borderless which creates issues in criminal jurisdiction for prosecution (Broadband Commission, 2011, p. 22) and need for collaboration between states; sexual abuse that is an act facilitated by use of the internet, as any other type of sexual offences, fits into a dark figure of crime, as many cases are being perpetrated but not reported. Just as other sex offences, it leaves immense consequences on its victims, with consequences increasing when the victim is a child. The feeling of shame, guilt, loss of confidence (Hamilton, 2017, p. 14), and anxiety that stays for life, together with potential physical consequences are only a few to mention. 
A brief discourse about the need for criminalization of online grooming...

The variety of consequences is accompanied by a variety of actions that are being perpetrated online, that cause victimization of children. Although Sonia Livingstone and Lesslie Hadden in EU kids online (2010, p. 237) have defined a set of categories of risk to harm related to online activities: "online harm from content, harm from contact and harm from conduct", Gallagher et al. (2006, p. 13) provided a more detailed list of categories of internet child sexual abuse: "international computer sexual abuse victimization, internet child sexual abuser, internet movement of children sexual abuse, internet-initiated grooming of a child for purposes of sexual abuse, internet-initiated incitement or conspiracy to commit child sexual abuse, internet-based child sexual abuse and internet-based receipt by children".

The focus of this paper is a particular criminal offence of online grooming. After presenting its characteristics, the author will offer a review of legal regulation in Bosnia and Herzegovina and provide arguments on why it is important for this to be criminalized. In that context, various international sources of criminal law will be presented, together with a legal analysis of relevant provisions of the positive law of selected countries that have already recognized social negativity of this phenomenon and criminalized it as a criminal offence. We find that the responsibility of Bosnia and Herzegovina, as a member state of these international documents, to accept their recommendations of criminalization of online grooming, its criminalization in one part of the territory of Bosnia and Herzegovina, and the increasing figures of cases of this criminal offence in that part of the country, in their combination, are valuable arguments in favor of criminalization of this criminal offence in Bosnia and Herzegovina. For purpose of proving that, comparative and normative scientific methods will be used.

This paper falls into four parts: first, the introductory part, which will offer an insight into the definition of "grooming" and its characteristics; the second part is a legal and critical analysis of the positive criminal law of Bosnia and Herzegovina. The third part consist of two logically connected units: an overview of international documents and legal analysis of comparative legal solutions related to grooming - all with the intent of providing arguments why it is necessary to have this action criminalized in Bosnia and Herzegovina. The final part concludes this discourse.

\subsection{A Few Remarks About Grooming}

Criminal law is primarily national law, so in order to establish a precise definition of "grooming" in each country, it is required to consult relevant provision of the criminal code. However, since internet abuse of children in its different forms became a growing problem, together with definitions of this criminal offence in the national laws (where it is prescribed), there are theoretical definitions that intend to summarize most of its characteristics and 
are of descriptive nature. In the Child Safety Online Report (2011, p. 2), grooming is widely described as "the process by which an individual befriends a young person for online sexual contact, sometimes with the involvement of webcams that can allow sharing of the exploitation among networks of child abusers, and sometimes extending to a physical meeting to commit sexual abuse". (Hamilton, 2017, p. 12) and Breech and Collings (2013), define it as "perpetrator forging a close relationship with a victim via technology in order to gain the child's compliance in and secrecy around subsequent sexual abuse", while in the International Center for Missing and Exploited Children's (2017, p. 9) report, it is similarly described as "the act of befriending and influencing a child and sometimes the child's family as well, for purpose of preparing the child for sexual activity". Klimek (2020, pp. 8-9) quotes Dean's (2007, p.65) definition of grooming as "friendly, flattering or supportive actions intended to win the trust of a child as a first step toward the sexual abuse of that child".

Whether a wide or narrow definition is observed, the essence of this criminal conduct is to abuse a child's lack of experience, gullibility and awareness of danger, with the internet as a means of connection, in order to achieve confidence, with an intent to establish a real-life meeting and to commit a sexual criminal offence. Therefore, "grooming" represents a dual-act, intentional criminal offence, whose actions may be temporally distant, but are contextually and causally connected. The grooming can take place both online and offline. However, the first act -the act of establishment of connection, is accompanied by child manipulation of different forms, including sending gifts, showing compassion about social or family problems, sharing common interests or presenting fake self-identity. The result of the survey from 2008, which shows that " $17 \%$ of children met the persons they reached online" (Rabotić, 2015, 89) is worrying.

The perpetrator of this criminal offence may be any person, regardless of age, gender or other characteristics. However, Stanley (2001, p. 4) alleges that usually perpetrators are "mature aged men, who are known to a child". Often, while using all the advantages of internet and potential to create a user profile based on their imagination, they create an image of themselves that triggers the feeling of trust with their victim. Klimek (2020, p.10) correctly notices that "the online groomer can create a profile of anybody, for example, a kind adolescent, a smart student, a successful sport player, or a grown-up university graduate at the beginning of professional career." Their contact may last for few days, months, years or as long as it takes to convince the victim of the reality and honesty of their relationship.

The passive subject is a child, "...a person who is below the age of 18 years..." (Convention on the Rights of a Child, 1989, Article 1). According to the data from 2017 (UNICEF, 2017, p. 7), "most endangered are children from separated families, children on the move, children living through conflict and children with disabilities". Middlesex University Study illustrates the severity of this criminal offence and vulnerability of children through the fact that it 
takes about three minutes for the perpetrator to start talking about sexual topics with children, and eight minutes to create a bond (International Center for Missing and Exploited Children, 2017, p. 10). In the same document (p. 12), four stages of grooming are identified:

- "Friendship relationship forming stage;

- Risk assessment;

- Exclusivity;

- Sexual stage".

Gallagher et al. (2006, p. 37) created a typology of grooming, in order to illustrate the variety of actions and other variables. According to them, there are four types of grooming:

- "Victim and offender live in the same country;

- Offender travels to victim's country;

- Victim travels to offender's country;

- Victim and offender travel to a third country".

This categorization not only presented the variety of possibilities in the perpetration of this criminal offence, but it also emphasized the potential jurisdiction issues in cases of this criminal offence, as it includes different countries.

\section{Diversity of approach in Bosnia and Herzegovina}

The growing numbers of victimizations of children, and sexual abuse through the internet worldwide, challenge national law fighting this type of crime. One of the countries that should work intensively on the creation of a legislative and practical framework in the prevention of online grooming is Bosnia and Herzegovina. Bosnia and Herzegovina's specific constitutional organization and division of jurisdictions in legislation among the State, two entities: Federation of Bosnia and Herzegovina and Republika Srpska, and Brčko District BH confirms a relation to criminal law division of jurisdiction. Respectively, there are four Criminal Codes in legal force, but only the entity codes and the Criminal Code of Brčko District $\mathrm{BH}$ have provisions related to sex offences. However, since the subject of our interest is particularly criminal offence regulating grooming through the use of internet communication, it can be said that such provision is present only in the Criminal Code of Republika Srpska, while other Criminal Codes that are the essence of the criminal positive law at the territory of Bosnia and Herzegovina do not incriminate such conduct.

The Criminal Code of Republika Srpska has shown its particular concern towards juveniles who may become victims of sex offences, and consequently devotes an entire chapter XV to sex offences that may be perpetrated on juveniles. In the same chapter it prescribes as a criminal offence the use of computer network and communication with other technical devices for perpetration of criminal offences of sexual molestation or use of a child. 
According to Article 178 Paragraph 1, the basic form of this criminal offence consists of two-act action: organizing a meeting with a child older than 15 , using a computer network or communication with other means. The criminal offence is completed by showing up at an agreed upon place. The essential element of the body of this crime is the motive: "sexual intercourse or with it equalized sexual act or production of pornography" (article 178 (1)). It is obviously an intentional criminal offence with dual intent. There is the knowledge and the will about organizing a meeting with a child and the knowledge and the will about committing a sexual offence. The object of protection is a child older than 15 years of age. Punishment is imprisonment from one to five years.

The aggravated form of this criminal offence is prescribed in the following paragraph, which consists of the same action as prescribed in paragraph 1, but which is perpetrated on a child younger than 15 years of age. The younger age of a child is an aggravating circumstance in this case, that caused the punishment to be prescribed harder: from two to eight years of imprisonment.

The lack of a similar provision in the Federation of Bosnia and Herzegovina and Brčko District BH shows lack of harmonization of criminal law in Bosnia and Herzegovina and uneven approach (Mapa puta, 2017, p. 32) in the fight against the existing social threat that endangers children. Data shows there is an obvious growth of all sexual offences against children: in 2019 there were 16 criminal offences, while in 2020 the number doubled as it is 34 (zastone.ba). From that number, there is a tendency of growth in the perpetration of criminal offence Use of computer network and communication with other technical devices for perpetration of criminal offences of sexual molestation or use of child, as its number from 2019 (2) has increased to 7 in 2020 (zastone.ba). Consequently, that indicates that for 2019, this criminal offence's intake in the sexual offences against children was $12,5 \%$, while one year later it was $20,5 \%$. These figures prove that this phenomenon is spreading. That and the fact that there is a need to have criminal codes harmonized in one country, shows that its criminalization is an important step to be taken.

\section{International and comparative overview of legal regulation of online grooming}

If an increase in the probability of the perpetration of this criminal offence, as the internet is approachable to all, and the fact there is already criminalization in one part of Bosnia and Herzegovina are not sufficient arguments in favor of criminalization of it in entire Bosnia and Herzegovina, there are additional arguments to offer as well. There are many international documents, whose member is Bosnia and Herzegovina, that recommend states to criminalize these actions as criminal offences, and also many states that offer a good example of dealing with a challenge that online grooming represents. 
A brief discourse about the need for criminalization of online grooming...

That is why in the further text, both international and comparative legal analysis will be made.

\subsection{How international documents refer to online grooming?}

The best interest of children and their protection from online activities were objects of interest in many international legal sources which deal with sexual violence. One of the most important legal sources that deals with the protection of the best interest of the child is the Convention on the Right of a Child (1989). Not only does it fully regulate the legal status of children and stipulates their rights and duties of other parties, in the article 34, it establishes the responsibility of state members to protect children from all types of sexual abuse.

Within the Convention of Cybercrime No. 185, which is the first treaty on crimes committed via the Internet and other computer networks, member states are obliged to adopt legislation and other measures within the national law, with an aim of preventing internet-related crimes, including various forms of pornography (Article 9). This issue remained the focus of many other international documents. It is also noteworthy to mention the Optional Protocol to the Convention on the Rights of the Child on the Sale of Children, Child Prostitution and Child Pornography (2000) that after showing concern for the potential victimization of children on the internet and other evolving technologies, brings up the importance of closer cooperation and partnership between governments and the Internet industry. That indicates the necessity of jurisdictions to update their criminal codes and think about the criminalization of new sex abuse related criminal offences that can be perpetrated by the use of the internet.

While Recommendation CM Rec (2009) recognizes potential in the internet sphere, it also describes harmful forms of behavior, such are the solicitation, online pornography and many other (par. 2), Recommendation $\mathrm{Cm}$ Rec (2014) also recognizes potential in internet sphere for harm to children (par. 94),

One of the most important international legal sources and instruments that deals with the protection of children from sexual abuse is the CE Convention on the Protection of Children against Sexual Exploitation and Sexual Abuse (2007). In Article 1 its defines its purpose as: "preventing and combating sexual exploitation and sexual abuse of children; protecting the rights of child victims of sexual exploitation and sexual abuse and promoting national and international co-operation against sexual exploitation and sexual abuse of children." It identifies various forms of actions to be criminalized as a form of sexual abuse and exploitation of children. It obliges the member states to take "the necessary legislative or other measures to prevent all forms of sexual exploitation and sexual abuse of children and to protect children" (Article 4). It defines the criminal offence "Solicitation of children for sexual purposes" (Article 23), and obliges member states to take "necessary legislative or other measures to criminalize the intentional proposal 
by an adult, through information and communication technologies, to meet a child" (Article 23) who has not reached the adulthood, for purpose of committing sexual abuse-related criminal offence against him or her, "where this proposal has been followed by material acts leading to such a meeting " (Article 23). It is noteworthy to mention that this criminal offence "prior this Convention had never been anchored by international legislative instruments" (Klimek, 2020, 12).

In 2015, the Committee of the Parties to the Council of Europe Convention on the Protection of Children against Sexual Exploitation and Sexual Abuse offered "Opinion on Article 23 of the Lanzarote Convention" and provided the explanatory note. Just as the title indicates, the idea was to provide details about the background of prescribing Article 23 which introduced a new criminal offence. It states that member states should prevent the commitment of sexual offences, including online grooming against children through information and communication technologies (par. 16) and also explains that for the existence of this criminal offence it is not necessary to have a meeting that results in contact, only that all the actions are taken with the intent (Par. 155) to result in a connection that may be of a sexual nature, including pornography. The Committee recommended for future criminalization to cover not only sexual abuse that is the result of a meeting in person, but also cases when it is committed online.

Directive 2011/92/EU of The European Parliament and of The Council of 13 December 2011 on Combating the Sexual Abuse and Sexual Exploitation of Children and Child Pornography ${ }^{1}$, established minimum rules concerning the definition of criminal offences and sanctions in the area of sexual abuse and sexual exploitation of children, child pornography and solicitation of children for sexual purposes (Article 1). Article 6 refers to solicitation of children for sexual purposes and obliges member states of the European Union to prescribe punitive measures against it. Many noticed (Klimek, 2020, p. 14) that the wording of that provision is a call for action and the criminalization is "explicitly premised". Furthermore, it is defined as "the proposal of and adult, by means of information and communication technology, to meet a child who has not reached the age of sexual consent, for the purpose of committing any of the sexual offences, where that proposal was followed by material acts leading to such a meeting, shall be punishable by a maximum term of imprisonment of at least one year". This was intended to achieve uniformity in prescription and understanding of what this criminal offence is.

Among the most recent developments related to this topic, it is important to mention Recommendation from 2018. The "Recommendation of the Committee of Ministers to member States on Guidelines to Respect, Protect and Fulfill the Rights of the Child in the Digital Environment" (2018) emphasizes that children are entitled to protection from all forms of violence,

\footnotetext{
${ }^{1}$ Although Bosnia and Herzegovina is still not a member state of the European Union, it is a country with intention to become one, so it is important to follow up the EU sources of law in legi ferenda.
} 
A brief discourse about the need for criminalization of online grooming...

abuse and molestation in a digital environment (par. 3.6) and all measures taken by the state should take into consideration the best interest of a child. This Recommendation also identifies various forms of harmful behaviors within the internet environment where the children are potential passive subjects. One of them is the use of internet for grooming, incitement of children on certain behaviors, including sexual abuse. It recommends that member states have those things in mind and create a legal framework that will provide a definition of the criminal offence, criminal, civil and administrative responsibility. This provision is important because it recommends to member states the creation of criminal liability for such behavior.

\subsection{A Few Positive Examples on Criminalization of Online Grooming}

Many countries from the region and beyond follow the recommendations of these international and regional documents. Croatian Criminal Code (2011) prescribes inciting children at satisfying sexual needs as a criminal offence. Article 161 (1) prescribes punishment from six months to five years for an individual who suggests meeting with an individual younger than 15 years of age or another person, by using information-communicational technologies or other methods. The criminal offence is completed if the meeting with the minor occurs. It is important to note here that the legislature, by prescribing "a minor or another person" as passive subjects, widened the potential for incrimination.

A similar provision, but with a narrower spectrum of potential passive subjects is prescribed in the Slovenian Criminal Code (2012), which through article 173a incriminates inciting minors under age of 15 for sexual purposes and prescribes criminal sanction of "imprisonment up to one year" should "perpetrator address a person under the age of fifteen through an information or communication technologies for the purpose of committing a criminal offense sexual assault of minor under the age of 15 or for producing images, audiovisual or other objects of pornographic or other sexual content, and the address is accompanied by specific actions to meeting made possible". Based on this provision, the action of this criminal offence consists either in using information or communication technologies to commit sexual assault on the protected passive subject, or by using those technologies on the subject to produce pornography. This is an example of an intentional dual-act criminal offence, which is completed when the meeting takes place. The fact that the perpetrator has to use specific actions to make the meeting possible, implies the existence not only of dolus, but dolus praemeditatus in the case, as potential preparatory actions needs to be conducted.

The criminal offence of the use of computer network or communication with other technical devices for perpetration criminal offences against sexual freedom against juvenile is prescribed by the Article $185 \mathrm{~b}$ of Criminal Code of Republic Serbia (2005). The use of above-mentioned technologies "to schedule 
a meeting with the juvenile and showing up at that meeting, with intention to commit criminal offence such as rape, or sexual intercourse with a helpless person, or sexual intercourse with a child, or sexual intercourse through abuse of position, or prohibited sexual acts, or pimping and procuring, or mediation in prostitution, or showing, procuring and possessing pornographic material and minor person pornography or inducing a child to attend sexual acts". This provision illustrates the essence of the use of the internet and other communication technologies. They are used in order for another criminal offence to be achieved. That confirms the intent as a form of guilt in the perpetration of this criminal offence. The sanctions prescribed are both "imprisonment from six months to five years and a monetary fine" (Criminal Code of Serbia, 2005, Article 185b(1)), as an indicator of the sensitivity of passive subjects and decisiveness of the legislature to deter the perpetrator. This criminal offence also has its aggravating form, the age of the passive subject. According to article 185b (2), the punishment of imprisonment from one to eight years is prescribed in case its basic action is perpetrated on child.

A similar provision is present in the Macedonian Criminal Code (1996) which also prescribes as a criminal offence the incitement a child who has not turned 14 to sexual assault or other sexual act (Article 193b, Criminal Code, 1996) and criminalizes "scheduling a meeting by computer communication means or any other means of inciting a child who is not 14 to sexual assault or other sexual act or to the production of children pornography and who by such intention directly meets the juvenile". The sanction prescribed is imprisonment of one to five years.

When it comes to countries beyond the region, in order to illustrate their approach, we will analyze relevant provisions of the Criminal Code of the Republic of France, Austria and the United Kingdom, as examples of civil and precedent law. The Criminal Code of Republic of France (Art.222-24 (8), 1998) does not prescribe an individual computer-related sexual criminal offence, but instead, finds the use of communication network as a mean of establishment of contact between perpetrator and victim as a form of criminal offence, rape. The sanction prescribed is imprisonment of twenty years. On other hand, Austrian Criminal Code (1974), through the Section 208a prescribes as a criminal offence the initiation of sexual contact with minors, and prescribes imprisonment for up to two years in case of proposing a personal meeting with an underage person or arranging such a meeting with him/her and taking concrete preparatory action in order to hold the personal meeting with the aim of committing sexual-abuse-related criminal offence, by use of telecommunications, computers system or any other means. The legislation protects a wider population than in any of compared legislations, as it indicates that the passive subject is any underage person, which covers any person under the age of 18 , including both children and juveniles. Additionally, a wide prescription of means is visible, as not only online but "any other" (Section 208a (1)) contact is criminalized, including offline connection as well. Another 
A brief discourse about the need for criminalization of online grooming...

form of this criminal offence, which is punishable by imprisonment of up to one year or a fine, is the same action perpetrated in order to produce pornographic materials (Section 208a (2)). Finally, the Austrian legislation establishes obligatory legal grounds for the liberation of a person who abandons the actions and reports themselves to the authority (Section 208a (3)). Basically, this is an example of the voluntary abandonment and of legal consequence it may produce. In the United Kingdom, the Sexual Offences Act of 2003 "introduced grooming as a new criminal offence" (Brown et al., 2007, p.62). Section $15 \mathrm{~A}$ criminalizes sexual communication with a child. The criminal offence exists if an adult intentionally communicates with a child under 16 , if the communication is sexual or is intended to be sexual. The criminal offence is prescribed in a wider sense, since by prescribing "establishment of contact" obviously refers to both online and offline contact and covers "wide range of behaviors" (Brown et al., 2007, p. 63). The sanction prescribed is imprisonment of two years.

\section{Conclusion}

The timely reaction of society to the growing social phenomenon is crucial. Awareness of the vulnerability of children and the prevalence of their abuse through the Internet is confirmed in practice but also in a number of international or regional documents whose member is Bosnia and Herzegovina, which imply the need to define and prescribe online grooming as a criminal offense.

By comparative analysis, we found that the analyzed various states, such as Slovenia, Croatia, Serbia, Macedonia, France, Germany and United Kingdom, acted in accordance with such obligations, and prescribed this criminal offense. Action(s) of this criminal offence are more or less uniformly prescribed, and in terms of sanctions, the countries of the SEE region are prone to stricter penalties, prescribing a sentence of up to five years for this crime.

Bosnia and Herzegovina partially approached the problem, as "online grooming" is prescribed only in the Republika Srpska, while it remains uncriminalized in the Federation of $\mathrm{BiH}$ and the Brčko District of $\mathrm{BH}$. The criminalization of this crime in Republika Srpska is in line with international standards dealing with this topic. All persons under the age of 18 are protected by it. The increasing rates of this crime in Republika Srpska, in the past two years confirm it was reasonable to criminalize it and that its actions are present in the BH society. However, the absence of criminalization of this crime in the other entity of Bosnia and Herzegovina and in the Brčko District of BH results in legal uncertainty and discrimination against citizens of the same state. While one act is treated as criminal act and is punishable in one part of the territory of Bosnia and Herzegovina, it is not treated as criminal offence nor is punishable in the rest of the country, since there is a lack of such legal regulation. 
Having all this said, the federal and district legislators have an important task to responsibly approach this challenge and to criminalize this act as a criminal offence, either as a stand-alone, which is recommendable, or as an aggravated form of another crime. That is how the major step in the fight against online grooming will be made, and will make it possible to deal with a new set of challenges such are establishing of correct institutional approach, raising awareness about the criminal offence and, the importance of its reporting and collaboration between states in resolving specific cases that may appear on this regard.

\section{Reference list}

A dramatic rise in reports of online child sexual abuse. (n.d). Retrieved October 5, 2021 from ECPAT website, https://ecpat.org/online-child-sexualexploitation-and-abuse-a-review-of-norwegian-case-law/;

Broadband Commission for Sustainable Development's Working Group on Child Online Safety. (2019). Child Online Safety: Minimizing the Risk of Violence, Abuse and Exploitation online. 1-84. Retrieved from https://www.broadbandcommission.org/working-groups/child-safetyonline-2019/;

Convention of Council of Europe on Cybercrime No. 185 from Budapest (2001). Retrieved from https://www.coe.int/en/web/conventions/full-list?module=treatydetail\&treatynum=185, on December 2, 2021;

Council of Europe Convention on the Protection of Children against Sexual Exploitation and Sexual Abuse (2007). Retrieved from https://www.coe.int/en/web/conventions/full-list?module=treatydetail\&treatynum=201, on December 02, 2021;

Craven, S., Brown, S., \& Gilchrist, E. (2007). Current Responses to Sexual Grooming: Implication for Prevention. The Howard Journal of Criminal Justice, 46(1), 60-71;

Criminal Code of Republic France, (Official Gazette 1998-468 of 17/1998, amended 2003);

Criminal Code of Republic of Croatia, (Official Gazette of Republic of Croatia 125/11, 144/12, 56/15, 61/15, 101/17, 118/18, 126/19, 84/21);

Criminal Code of Republic of Macedonia, (Official Gazette of the Republic of Macedonia 37/1996, 80/1999, 4/2002, 43/2003, 19/2004, 81/2005, 60/2006, 73/2006, 7/2008, 139/2008, 114/2009, 51/2011, 135/2011, 185/2011, 142/2012, 166/2012, 55/2013, 82/2013, 14/2014, 27/2014, 28/2014, 41/2014, 115/2014, 132/2014, 160/2014, 199/2014, 196/2015, 226/2015, 97/2017, 248/2018); 
Criminal Code of Republic of Serbia, (Official Gazette of Republic of Serbia No. br. 85/2005, 88/2005, 107/2005, 72/2009, 111/2009, 121/2012, 104/2013, 108/2014, 94/2016 i 35/2019);

Criminal Code of Republic of Slovenia, (Official Gazette of Republic of Slovenia 50/12, 6/16, 54/15, 38/16, 27/17, 23/20, 91/20, 95/21);

Criminal Code of Republika Srpska (Official Gazette 64/2017, 104/2018, 15/2021);

Criminal Code of the Republic of Austria (1974, amended 2019). Retrieved from https://www.legislationline.org/documents/section/criminalcodes/country/44/Austria/show, on 15.09.2021.;

Declaration by the Committee of Ministers on the need to protect children's privacy in the digital environment. (2021). Retrieved from https://search.coe.int/cm/pages/result_details.aspx?objectid=0900001 680a2436a;

Gallagher, B. (Ed.). (2006). International and internet child sexual abuse and exploitation: Research report. University of Huddersfield, Huddersfield, UK. from http://eprints.hud.ac.uk/id/eprint/461/;

Hamilton-Giachritsis, C. (2017). "Everyone deserves to be happy and safe": A mixed methods study exploring how online and offline child sexual abuse impact young people and how professionals respond to it. Retrieved from http://dx.doi.org/10.13140/RG.2.2.35001.88164;

Safe Online, https://www.end-violence.org/safe-online accessed on December 02, 2021;

International Center for Missing and Exploited Children. (2017). Online Grooming of Children for Sexual Purposes: Model Legislation and Global Review. 1-67;

Kelsen, H. (2006). General Theory of State and Law; with a new introduction by A. Trevino. USA: Library of Congress.

Klimek, L. (2020). European Responses Criminalizing Online Solicitation of Children for Sexual Purposes. Balkan Social Science Review, Vol.16, 7-21.

Livingstone, S. and Haddon, L. (2010) EU kids online. Zeitschrift fur psychologie - Journal of psychology, 217 (4). pp. 236-239. ISSN 00443409

(5) $(P D F) \quad E U$ kids online. Retrieved from https://www.researchgate.net/publication/263912808_EU_kids_onlin e [accessed Dec 02 2021].

McGuire, M. and Dowling, S. (2013) Cyber crime: A review of the evidence. The Home Office. UK. 26. Retrieved from https://www.publicsafety.gc.ca/lbrr/archives/cnmcs-plcng/cn36762eng.pdf, [accessed Nov 01 2021];

Opinion on Article 23 of the Lanzarote Convention and its explanatory note. (2015). Committee of the Parties to the Council of Europe Convention on the protection of children against sexual exploitation and sexual 
abuse (T-ES). Retrieved from https://edoc.coe.int/en/children-srights/7064-lanzarote-committee-opinion-on-article-23-of-the-

lanzarote-convention-and-its-explanatory-note.html.

Optional Protocol to the Convention on the Rights of the Child on the sale of children, child prostitution and child pornography (2000). Retrieved from

https://www.ohchr.org/en/professionalinterest/pages/opsccrc.aspx;

Recommendation CM/Rec(2014)6 of the Committee of Ministers to member States on a Guide to human rights for Internet users. Retrieved from https://www.coe.int/en/web/freedom-expression/committee-ofministers-adopted-texts/-

/asset_publisher/aDXmrol0vvsU/content/recommendation-cm-rec2014-6-of-the-committee-of-ministers-to-member-states-on-a-guideto-human-rights-for-Internet-users-adopted-by-the-committee-of?_101_INSTANCE_aDXmrol0vvsU_viewMode=view/;

Recommendation CM/Rec (2016) 2 to member States on the Internet of citizens. $\quad$ Retrieved from https://search.coe.int/cm/Pages/result_details.aspx?ObjectId=0900001 6805 c20f4;

Recommendation of the Committee of Ministers to member States on Guidelines to respect, protect and fulfil the rights of the child in the digital environment $\mathrm{CM} / \operatorname{Rec}(2018)$. Retrieved from https://edoc.coe.int/en/children-and-the-internet/7921-guidelines-torespect-protect-and-fulfil-the-rights-of-the-child-in-the-digitalenvironment-recommendation-cmrec20187-of-the-committee-ofministers.html;

Recommendation CM/Rec (2009) of the Committee of Ministers to member States on measures to Protect Children against Harmful Content and Behaviour and to Promote their Active Participation in the New Information and Communications Environment. Retrieved from https://www.coe.int/en/web/freedom-expression/committee-ofministers-adopted-texts//asset_publisher/aDXmrol0vvsU/content/recommendation-cm-rec2009-5-of-the-committee-of-ministers-to-member-states-onmeasures-to-protect-children-against-harmful-content-and-behaviourand-?_101_INSTANCE_aDXmrol0vvsU_viewMode=view/;

Robotić, P. (2015). Zamke virtualnog svijeta: Zaštita djece i mladih na internetu $i$ prevencija ovisnosti [The Traps of the Virtual World: Protecting Children and Youth Online and Addiction Prevention]. Journal of Applied Health Sciences, 1(2), 81-96. https://doi.org/10.24141/1/1/2/1;

Stanley, J. (2001). Child abuse and the Internet. Australia: Australian Institute for Family Studies. 21;

Study on the Effects of New Information Technologies on the Abuse and Exploitation of Children. (2015.). UN.76. Retrieved from 
A brief discourse about the need for criminalization of online grooming...

https://www.unodc.org/documents/Cybercrime/Study_on_the_Effects .pdf;

UNICEF. (2011). Child safety online: Global challenges and strategies. Unicef. Retrieved from http://www.unicef.it/Allegati/Child_Safety_Online_1.pdf;

United Kingdom Sexual Offences Act. Retrieved from https://www.legislation.gov.uk/ukpga/2003/42/contents, on Oct 15, 2021;

UNICEF. (2020). What Works to Prevent Online and Offline Child Sexual Exploitation and Abuse? 1-76. Retrieved from https://www.unicef.org/eap/media/4706/file/What\%20works.pdf, on Oct 18, 2021;

Zaimović, A. (2017) Mapa puta borbe protiv seksualnog i drugih oblika nasilja nad djecom na internetu u Bosni i Hercegovini [Road Map of Fight against Sexual and Other Forms of Violence against Children on the Internet in Bosnia and Herzegovina]. Sarajevo: Save the Children; 
